\title{
COMMUNICATIONS
}

\section{SPECIFICITY AND COMPARATIVE ACTIVITY OF THE CARBONIC ANHYDRASE INHIBITORS NEPTAZANE AND DIAMOX ON ANIMAL AND HUMAN EYES*}

\author{
BY
}

\author{
MAURICE E. LANGHAM $\dagger$
}

From the Howe Laboratory of Ophthalmology, Harvard Medical School, and the Massachusetts Eye and Ear Infirmary, Boston, U.S.A.

IN an investigation of the function of the enzyme carbonic anhydrase in the formation of the aqueous humour (Langham, 1958b), studies were made with a new carbonic anhydrase inhibitor, 5-acetylimino-4-methyl- $\Delta^{2}-1,3$, 4thiadiazoline-2-sulphonamide (Neptazane, Lederle Laboratories). The results of this study indicated that Neptazane was more active than the wellknown carbonic anhydrase inhibitor Diamox in reducing the intra-ocular pressure and the rate of formation of the aqueous humour, and were consequently thought to be of sufficient clinical interest to be presented in this paper. Neptazane differs pharmacologically from Diamox in that it has greater in vitro activity, penetrates the blood-brain barrier more rapidly, and is excreted from the body more slowly (unpublished reports, Lederle Laboratories). Recently, Becker (1957) summarized his own unpublished studies and stated that Neptazane was three to four times more active than Diamox in decreasing the intra-ocular pressure of animals and man, and that side reactions were much less common in patients given Neptazane.

In separate studies to be described in this paper, the specificity of these two potent carbonic anhydrase inhibitors has been analysed by the use of compounds having similar chemical structure but possessing no inhibitory activity; the structures of the two inhibitors and two of their inactive control compounds are shown in Fig. 1 (overleaf). These control compounds differ from Neptazane and Diamox in not having a free sulphonamide group, a characteristic which is essential for carbonic anhydrase inhibitory action (Mann and Keilin, 1940; Krebs, 1948; Maren, 1956).

\section{Methods}

Albino rabbits of both sexes weighing between 1.8 and $3.0 \mathrm{~kg}$. and adult cats weighing 3 to $4.5 \mathrm{~kg}$. were used in these studies. Animals were anaesthetized with Urethane $(1.25$ to $1.75 \mathrm{~g}$. $/ \mathrm{kg}$.) given intravenously or intraperitoneally in a 25 per cent. solution $(\mathrm{w} / \mathrm{v})$.

Strain gauge manometers (Statham, California) coupled to the Sanborn model preamplifier and the Sanborn model $150-1,100$ direct pen recorder were used to record the intra-ocular and the femoral arterial pressures (Langham, 1958b).

* Received for publication May 20, 1958 
<smiles>CO[NH+]1c2nnc(s2)S1(=O)=O</smiles>

(a)<smiles></smiles>

(C)<smiles>CC(=O)Nc1nnc(S(=O)(=O)O)s1</smiles>

(b)

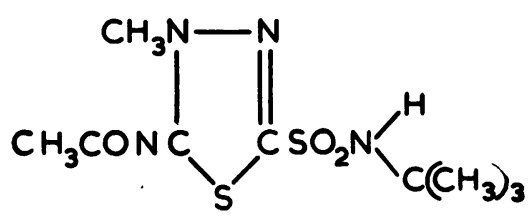

(d)

FIG. 1.-Chemical structure of carbonic anhydrase inhibitors

(a) Diamox, 2-acetylamino-1, 3, 4-thiadiazole-5-sulphonamide

(b) Its inactive control compound, 2-acetylamino-1, 3, 4-thiadiazole-5 $\mathrm{N}$-methyl sulphonamide

(c) Neptazane, 5 acetylimino-4 methyl- $\Delta^{2}-1,3$, 4-thiadiazoline-2-sulphonamide

(d) Its inactive control compound, 5-acetylimino-4-methyl-42-1, 3, 4-thiadiazoline-2N-t-butyl sulphonamide.

The rate of formation of the aqueous humour was recorded by a direct procedure described by Langham (1958b). The aqueous humour of the anterior chamber was replaced by liquid paraffin (mineral oil) to block the outflow vessels and the aqueous humour secreted into the posterior chamber flowed into a graduated micro pipette maintained at a constant pressure of $35 \mathrm{~mm}$. $\mathrm{Hg}$.

Tonometry on rabbits was made with a standard Schiötz tonometer with a $7 \cdot 5$-g. load. Rabbits were placed in a canvas bag to restrain movement, and readings were taken with the animal on its side after placing one drop of 1 per cent. solution of pantocaine into the subconjunctival sac.

Tonometry on human subjects was made with either a standard X-tonometer (5.5 g. wt) or the standard Mueller electronic tonometer.

Diamox, Neptazane, and the control inactive compounds were used in a 2 per cent. solution of their sodium salt. These solutions had a pH of 9 to 10.*

\section{Results}

Representative experimental records of the maximal effect of an intravenous injection of Neptazane and Diamox on the intra-ocular pressure of cats are shown in Figs 2 and 3 (opposite).

The results in cats and rabbits were essentially identical, and in all the animals studied Neptazane caused the intra-ocular pressure to fall independently of the blood pressure, and to approach a new steady-state value in 10 to $20 \mathrm{~min}$. The extent of the change in intra-ocular pressure in three rabbits and three cats injected with varied amounts of Neptazane are recorded in Table I (overleaf).

Diamox given to a rabbit which had previously been injected with Neptazane caused no further fall in the intra-ocular pressure (Fig. 4, overleaf).

The inactive control compound of Neptazane had no effect on the steady-state value of the intra-ocular pressure in rabbits or cats when injected intravenously in amounts

* Samples of the two inhibitors and their contro compounds were generously donated by Lederle research laboratories. 

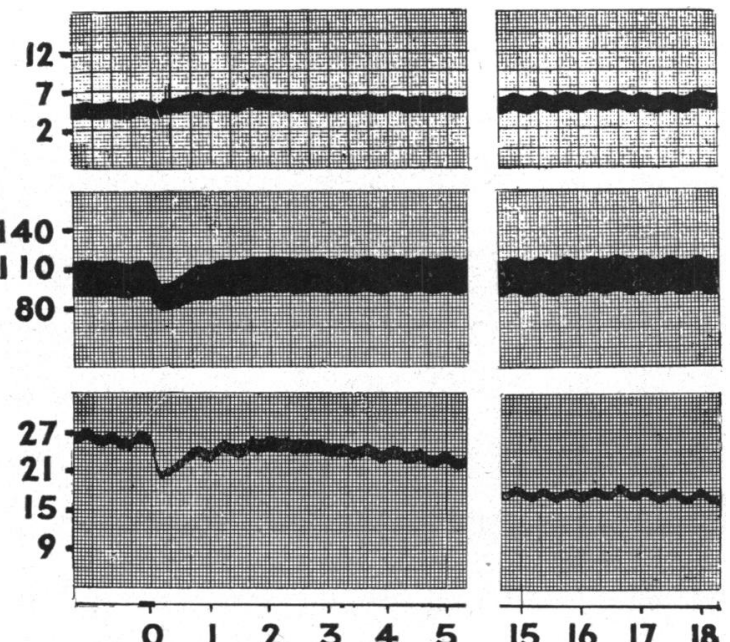

FIG. 2.-Effect of an intravenous injection of $20 \mathrm{mg}$. $/ \mathrm{kg}$. Neptazane on intra-ocular pressure, femoral arterial blood pressure, and cerebrospinal pressure of an adult cat anaesthetized with Urethane. A 2 per cent. solution of the sodium salt of Neptazane was injected into the femoral vein at the time marker $(t=0$ min. $)$. TIME (min.)

Fig. 3.-Effect of an intravenous injection of $20 \mathrm{mg} . / \mathrm{kg}$. Diamox on intra-ocular pressure, femoral arterial blood pressure, and cerebrospinal pressure of an adult cat anaesthetized with Urethane. Diamox was injected into the femoral vein at the time marker ( $t=1 \mathrm{~min}$.).

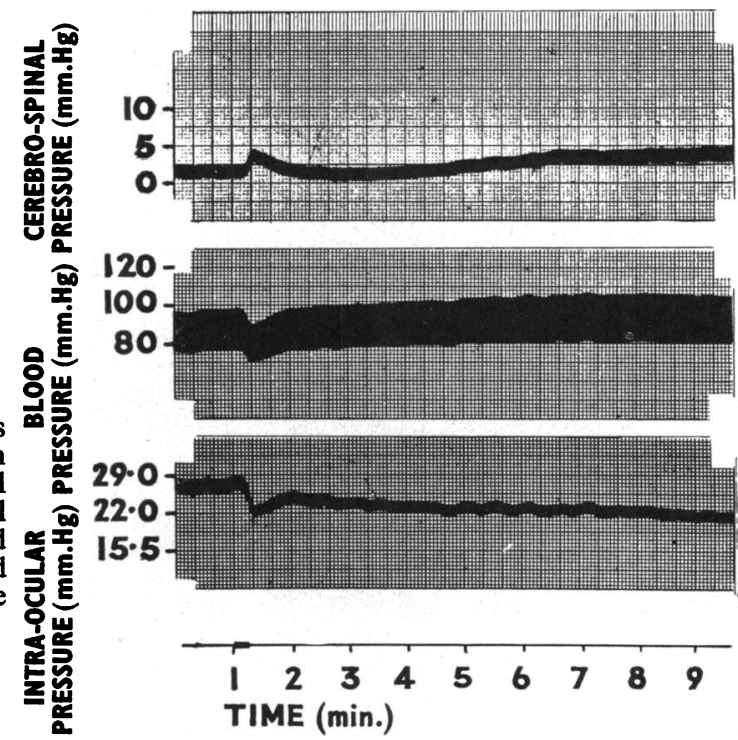

up to $100 \mathrm{mg} . / \mathrm{kg}$. (Fig. 5, overleaf). However, the same animals were found to give a typical response to an intravenous injection of Neptazane at a dose of 2 to $5 \mathrm{mg} . / \mathrm{kg}$. Similar results were obtained when the inactive control compound of Diamox was injected intravenously in doses of $100 \mathrm{mg}$./kg. (Fig. 6, overleaf). Fig. 7 (overleaf) shows the effects on a rabbit which had been found to be unaffected by an intravenous dose of $50 \mathrm{mg}$. $/ \mathrm{kg}$. of the inactive control compound, but in which the intra-ocular pressure fell dramatically after a subsequent intravenous injection of $5 \mathrm{mg} . / \mathrm{kg}$. Diamox.

A comparison of the activities of Neptazane and Diamox in causing a fall in the intraocular pressure was made in a series of experiments on conscious rabbits using a standard Schiötz tonometer to measure the intra-ocular pressure, and in a further small series of experiments using the manometric procedure on anaesthetized rabbits. In a group of four conscious rabbits a significant fall in the intra-ocular pressure occurred after an intravenous injection of $1 \mathrm{mg}$./kg. Neptazane (Fig. 8, overleaf), while in a similar series of 
TABLE I

EFFECT OF NEPTAZANE INJECTED INTRAVENOUSLY ON THE INTRA-OCULAR PRESSURE OF ANAESTHETIZED RABBITS AND CATS

Final intra-ocular pressure read $20 \mathrm{~min}$. after injection of Neptazane

\begin{tabular}{|c|c|c|c|c|c|c|c|}
\hline & \multirow{2}{*}{\multicolumn{3}{|c|}{ Animal }} & \multirow{2}{*}{$\begin{array}{l}\text { Neptazane } \\
\text { (mg./kg.) }\end{array}$} & \multirow{2}{*}{$\begin{array}{l}\text { Blood Pressure } \\
\text { (mm. Hg) }\end{array}$} & \multicolumn{2}{|c|}{ Intra-Ocular Pressure } \\
\hline & & & & & & Initial & Final \\
\hline $\begin{array}{l}\text { Rabbit } \\
\text { Rabbit } \\
\text { Rabbit }\end{array}$ & $\begin{array}{l}\cdots \\
\cdots \\
\cdots\end{array}$ & $\begin{array}{l}\cdots \\
\cdots \\
\cdots\end{array}$ & $\begin{array}{l}\cdots \\
\cdots \\
\cdots\end{array}$ & $\begin{array}{r}50 \\
20 \\
1\end{array}$ & $\begin{array}{l}110 \\
120 \\
150\end{array}$ & $\begin{array}{l}21 \\
17 \\
20\end{array}$ & $\begin{array}{l}16 \\
13 \\
16\end{array}$ \\
\hline $\begin{array}{l}\text { Cat } \\
\text { Cat } \\
\text { Cat }\end{array}$ & $\begin{array}{l}\cdots \\
\cdots \\
\cdots\end{array}$ & $\begin{array}{l}\cdots \\
\cdots \\
\cdots\end{array}$ & $\begin{array}{l}\cdots \\
\cdots \\
\cdots\end{array}$ & $\begin{array}{r}20 \\
2 \\
1\end{array}$ & $\begin{array}{l}100 \\
110 \\
140\end{array}$ & $\begin{array}{l}21 \\
18 \\
20\end{array}$ & $\begin{array}{l}16 \\
13 \\
15\end{array}$ \\
\hline
\end{tabular}

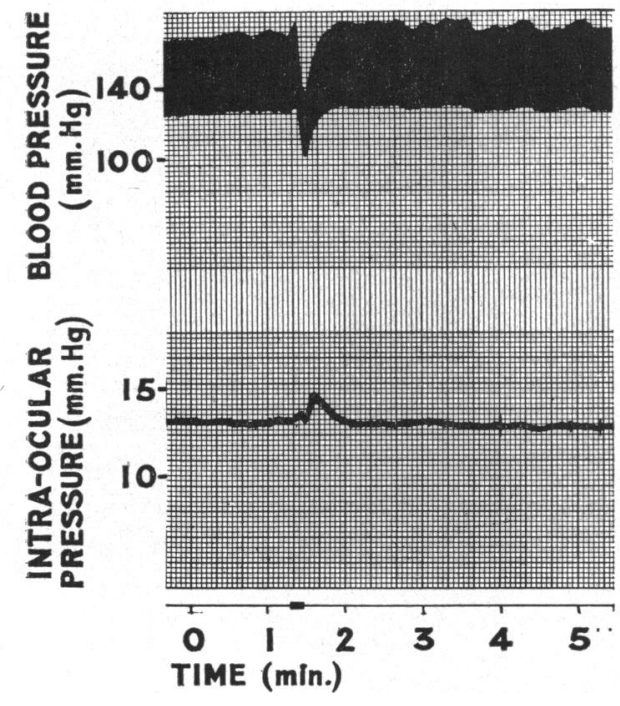

FIG. 4.-Action of $50 \mathrm{mg} . / \mathrm{kg}$. Diamox injected intravenously into a rabbit (at black mark) $20 \mathrm{~min}$. after an intravenous injection of 50 $\mathrm{mg} . / \mathrm{kg}$. Neptazane (Neptazane caused the intra-ocular pressure to fall from 20 to approximately $13 \mathrm{~mm}$. $\mathrm{Hg}$ in $20 \mathrm{~min}$.).

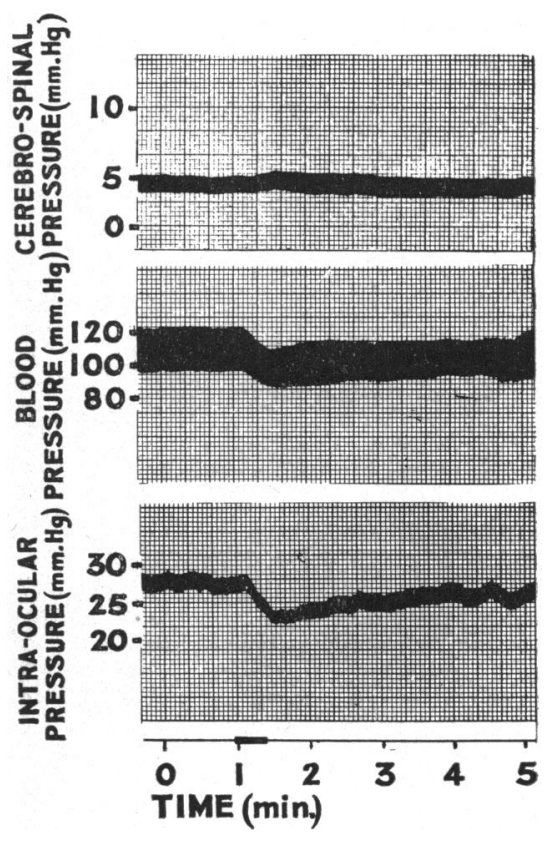

Fig. 5.-Effect of an intravenous injection of $50 \mathrm{mg} . / \mathrm{kg}$. of the inactive control compound of Neptazane on intra-ocular pressure, femoral arterial blood pressure, and cerebrospinal pressure of a cat anaesthetized with Urethane. A 2 per cent. solution of the sodium salt of the compound was injected into the femoral vein at $t=1 \mathrm{~min}$.

rabbits there was no change in the intra-ocular pressure after an intravenous injection of $1 \mathrm{mg}$. $/ \mathrm{kg}$. Diamox (Fig. 8). When Diamox was injected in a dose of $5 \mathrm{mg}$. $/ \mathrm{kg}$. there was a significant fall in the intra-ocular pressure of four rabbits. Fig. 8 shows that the fall in intra-ocular pressure after the injection of Neptazane was not maintained; thus tonometric readings taken 60 to $120 \mathrm{~min}$. after the injection approached the values 

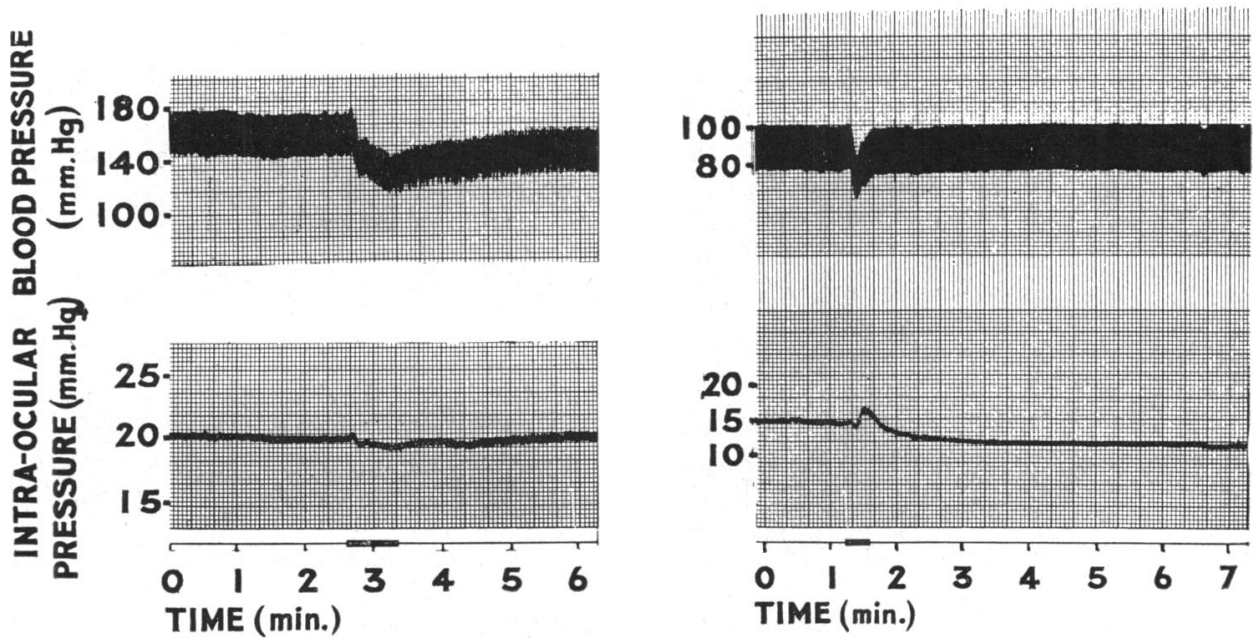

Fig. 6.-Effect of an intravenous injection of $50 \mathrm{mg} . / \mathrm{kg}$. of the inactive control compound of Diamox on intra-ocular pressure and femoral arterial blood pressure of a cat anaesthetized with Urethane.

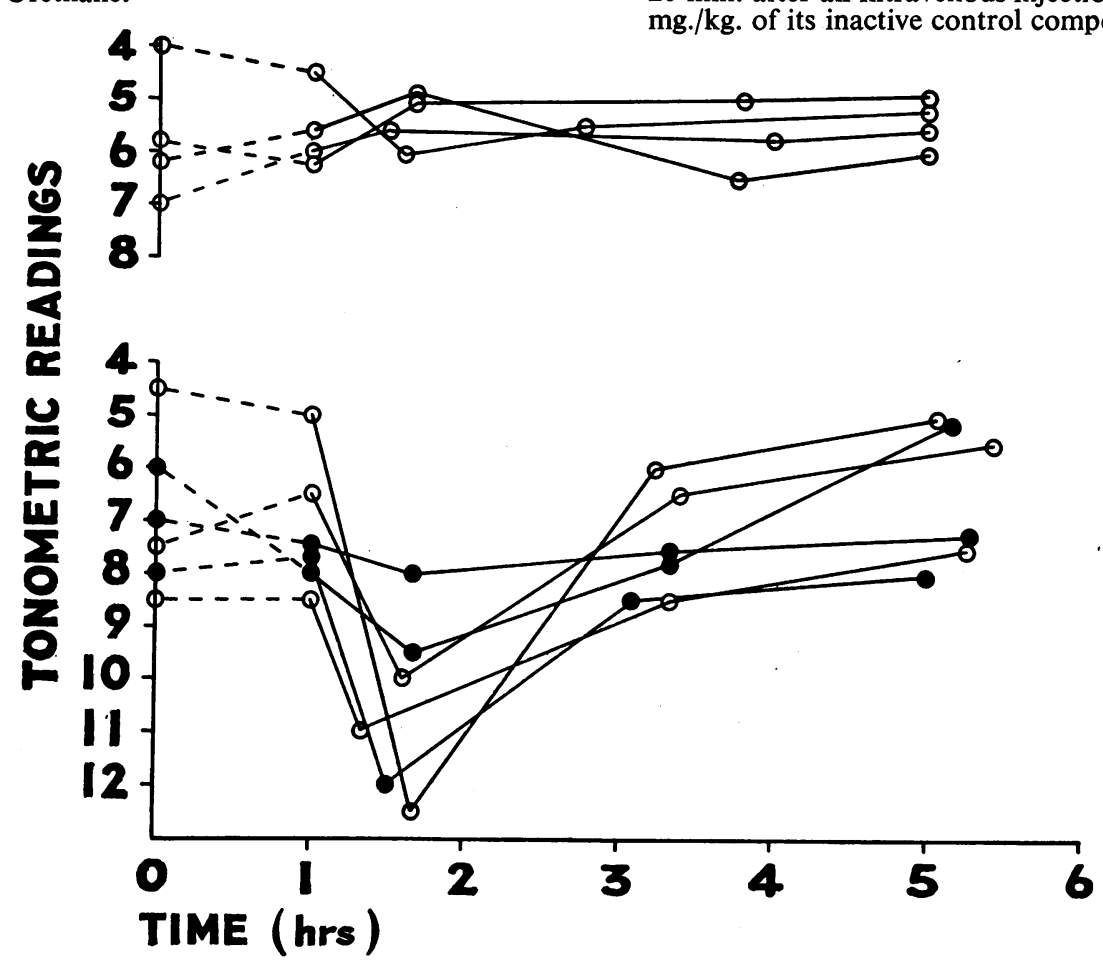

Fig. 7.-Effect of an intravenous injection of $20 \mathrm{mg} . / \mathrm{kg}$. Diamox on the intra-ocular pressure and femoral arterial blood pressure of a rabbit anaesthetized with Urethane, $20 \mathrm{~min}$. after an intravenous injection of 50 $\mathrm{mg} . / \mathrm{kg}$. of its inactive control compound.

FIG. 8.-Comparative action of Diamox and Neptazane on the intra-ocular pressure of conscious rabbits.

Upper figure shows tonometric readings (Schiötz $7.5 \mathrm{gm}$. wt) before and after the intravenous injection of $1 \mathrm{mg} . / \mathrm{kg}$. Diamox at $t=1 \mathrm{hr}$.

Lower figure shows tonometric readings before and after the intravenous injection of $1 \mathrm{mg} . / \mathrm{kg}$. ( $\bigcirc-\mathrm{O})$ and $2 \mathrm{mg} . / \mathrm{kg}$. (O-O) Neptazane at $t=1 \mathrm{hr}$. 
recorded before the administration of Neptazane. This recovery was also observed in rabbits given $5 \mathrm{mg} . / \mathrm{kg}$. Diamox and agreed with previous observations with this compound (Langham and Lee, 1957). An attempt to prolong the effect of Neptazane on the intra-ocular pressure by giving 5 or $10 \mathrm{mg}$. $/ \mathrm{kg}$. Neptazane was not successful, for again, tonometric readings taken 1 and $2 \mathrm{hrs}$ after the injection indicated a marked recovery of the intra-ocular pressure. In manometric studies on three anaesthetized rabbits, an intravenous injection of $1 \mathrm{mg}$. $/ \mathrm{kg}$. Diamox did not decrease the intra-ocular pressure, while a further injection of $1 \mathrm{mg}$. $/ \mathrm{kg}$. $10 \mathrm{~min}$. later caused a fall in the intra-ocular pressure in two out of the three animals. In similar studies on three other rabbits, an intravenous injection of $0.5 \mathrm{mg} . / \mathrm{kg}$. Neptazane did not cause a significant fall in the intra-ocular pressure within $10 \mathrm{~min}$. in two animals, while a further injection of $0.5 \mathrm{mg} . / \mathrm{kg}$. led to a significant decrease in the intra-ocular pressure in both animals. In the third rabbit the intra-ocular pressure fell after the injection of $0.5 \mathrm{mg} . / \mathrm{kg}$. Neptazane. The effect of an intravenous injection of $1 \mathrm{mg} . / \mathrm{kg}$. Neptazane on the intra-ocular pressure of a rabbit is recorded in Fig. 9.

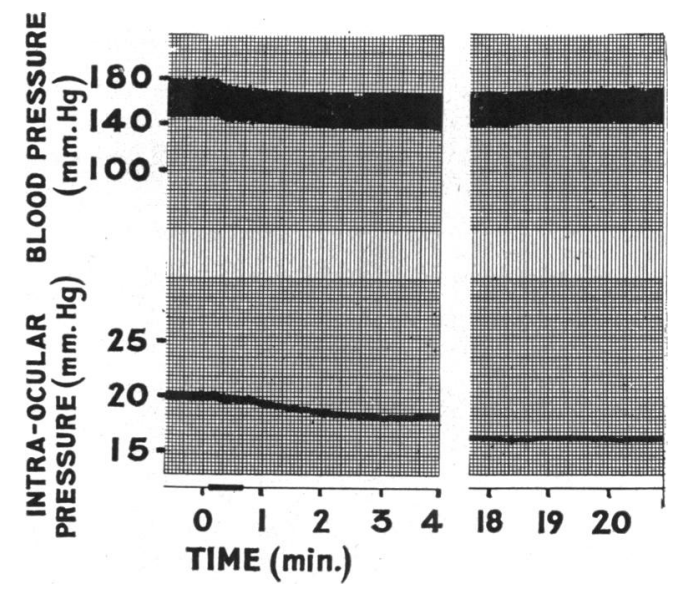

FIG. 9.-Effect of $1 \mathrm{mg}$./kg. Neptazane on intra-ocular pressure and femoral arterial blood pressure of a rabbit anaesthetized with Urethane. A 2 per cent. solution of the sodium salt of Neptazane was injected into the femoral vein at $t=1 \mathrm{~min}$.

Aqueous Humour Formation.-The conclusion that Diamox can reduce the rate of formation of aqueous humour has been based on indirect evidence from tonographic studies, the rate of appearance of fluorescein in the area of the pupil after an intravenous injection, and the analysis of the distribution of certain compounds between the fluids of the posterior and anterior chambers. An opportunity to study in greater detail than hitherto the effect of carbonic anhydrase inhibitors on the rate of formation of aqueous humour came with the development of a technique whereby the volume of aqueous formed may be continuously recorded (Langham, 1958b). Typical results of the effect of Neptazane and Diamox on the rate of formation of aqueous humour in anaesthetized rabbits are recorded in Fig. 10 (opposite). The rate of aqueous humour formation was unaffected by the intravenous injection of $50 \mathrm{mg} . / \mathrm{kg}$. of the inactive control compounds. In contrast, an intravenous dose of as little as $1 \mathrm{mg}$. $/ \mathrm{kg}$. Neptazane caused a rapid and significant decrease in the rate of aqueous humour formation in all of three rabbits tested. In these animals the rate of aqueous humour formation approached a new steady-state value in 10 to $15 \mathrm{~min}$. Under similar experimental conditions an intravenous injection of $1 \mathrm{mg} . / \mathrm{kg}$. Diamox caused no significant fall in the rate of aqueous humour formation, but a positive effect was observed in two rabbits injected with $2 \mathrm{mg} . / \mathrm{kg}$. 


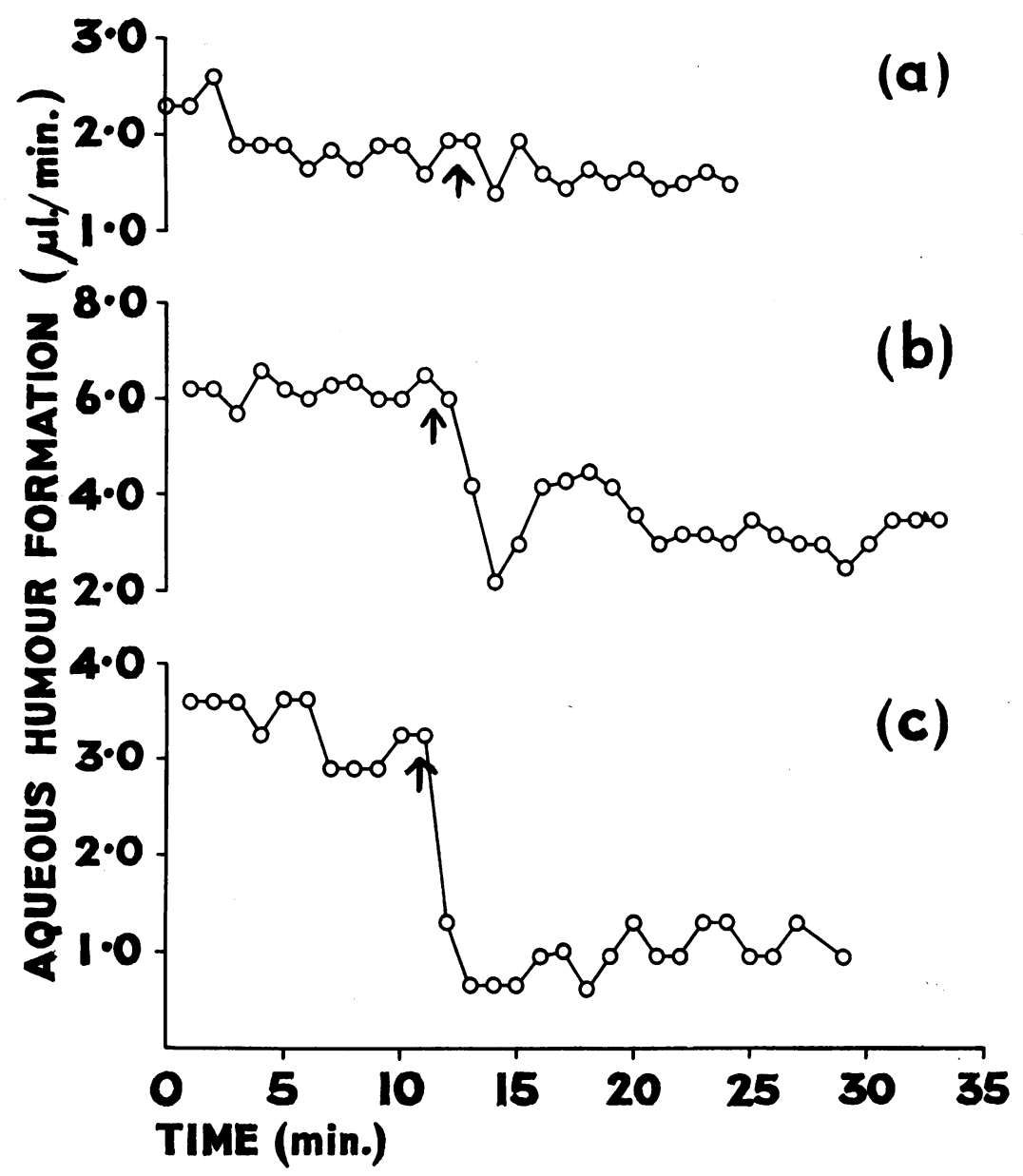

FIG. 10.-Rate of formation of aqueous humour of rabbits before and after the intravenous injection of:

(a) $50 \mathrm{mg} . / \mathrm{kg}$. of the inactive control compound of Diamox (at arrow)

(b) $5 \mathrm{mg} . / \mathrm{kg}$. Diamox (at arrow)

(c) $1 \mathrm{mg} . / \mathrm{kg}$. Neptazane (at arrow)

Intra-ocular pressure maintained at $35 \mathrm{~mm}$. $\mathrm{Hg}$ (Schiötz).

Human Studies.-Here, the principal object was to compare the activities of Neptazane and Diamox on the intra-ocular pressure of normal subjects over a 24-hr period. From a survey of the literature it appeared that it would be necessary to give $500 \mathrm{mg}$. Diamox by mouth to adults to obtain a maximal effect on the intra-ocular pressure. Thus Becker (1955) found that, in fifteen eyes of ten subjects given $500 \mathrm{mg}$. Diamox by mouth, the mean intra-ocular pressure fell from 17.6 to $14.6 \mathrm{~mm}$. $\mathrm{Hg}$ in $3 \mathrm{hrs}$, which corresponds to a decrease of approximately 50 per cent. in the rate of aqueous humour formation, on the assumption that the outflow resistance and the recipient episcleral venous pressure remained unchanged. In comparison an oral dose of $250 \mathrm{mg}$. has been reported to cause a fall of only 1 to $3 \mathrm{~mm}$. $\mathrm{Hg}$ in the eyes of normal subjects carrying on their usual activities (Grant and Trotter, 1954). In the first series of experiments, which are 
recorded in Fig. 11, four normal adult subjects and three patients with a diagnosis of chronic simple glaucoma were given $500 \mathrm{mg}$. Diamox every $6 \mathrm{hrs}$, and the intra-ocular pressure was determined periodically. In all eyes there was a significant fall in the intra-ocular pressure which showed no evidence of recovery during the 24-hr experimental period.

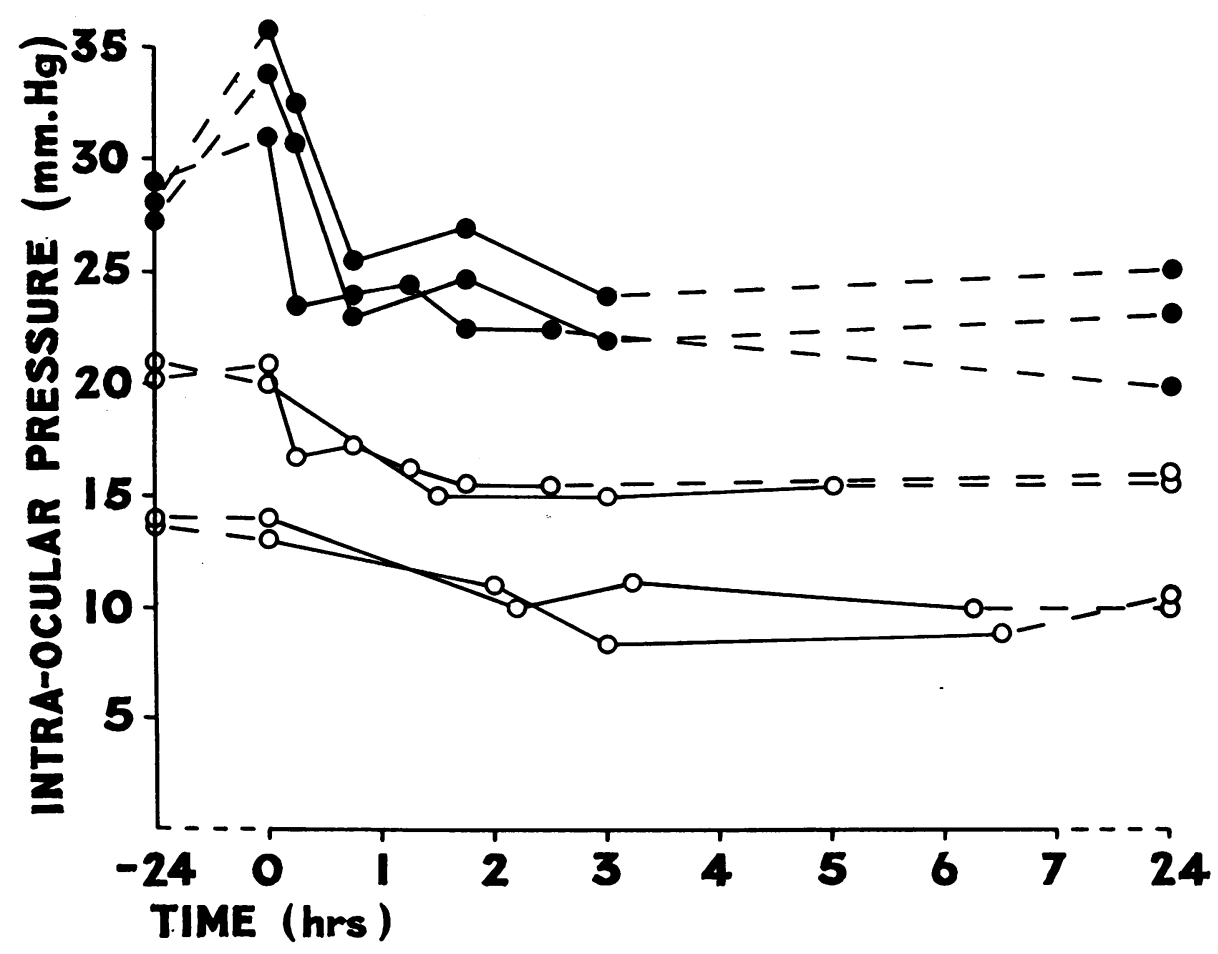

FIG. 11.-Effect of Diamox on intra-ocular pressure of normal $(\bigcirc-\bigcirc)$ and glaucomatous (०-O) human eyes.

The points for normal eyes represent the means from a pair of eyes; values for the glaucomatous eyes represent the mean from one eye.

Three of the four normal subjects were given $500 \mathrm{mg}$. Diamox orally at 4-hrly periods. The fourth normal subject and the three glaucomatous patients were given an initial intravenous injection of $500 \mathrm{mg}$. Diamox followed at 4-hrly periods by $500 \mathrm{mg}$. taken orally.

In a further series of experiments, $250 \mathrm{mg}$. Diamox were administered twice daily for 3 days, and the intra-ocular pressure was measured at regular time intervals during the day. The results recorded in Table II (opposite) indicate that in these conditions the intraocular pressure fell by an average of $1.7 \mathrm{~mm}$. $\mathrm{Hg}$. These two sets of observations are in agreement with the findings reported by Becker (1955) and Grant and Trotter (1954).

The results of studies on normal subjects and glaucoma patients given Neptazane in doses of 250 or $125 \mathrm{mg}$. twice daily, are recorded in Table III (opposite). In all six normal subjects, the intra-ocular pressure fell by 3 to $4 \mathrm{~mm}$. $\mathrm{Hg}$ within $2 \mathrm{hrs}$ and remained at this lowered level over the experimental period of $24 \mathrm{hrs}$. In those subjects given $250 \mathrm{mg}$., the intra-ocular pressure was found to remain low for more than $18 \mathrm{hrs}$ after the last dose. In the two subjects given $125 \mathrm{mg}$., the intra-ocular pressure was depressed for over $12 \mathrm{hrs}$, but showed signs of recovery after 16 hrs. No side-effects were noted in these subjects. 
TABLE II

EFFECT OF $250 \mathrm{mg}$. DIAMOX GIVEN TWICE DAILY ON THE INTRA-OCULAR PRESSURE OF NORMAL ADULTS

Numbers of readings in brackets

\begin{tabular}{|c|c|c|}
\hline \multirow{2}{*}{$\begin{array}{l}\text { Subject } \\
\text { No. }\end{array}$} & \multicolumn{2}{|c|}{ Mean Intra-Ocular Pressure } \\
\hline & Before giving Diamox & $\begin{array}{l}\text { Calculated from Readings taken } \\
\text { periodically during } 2 \text { to } 3 \text { days after } \\
\text { the First Dose of Diamox }\end{array}$ \\
\hline $\begin{array}{l}1 \\
2 \\
3 \\
4 \\
5 \\
6\end{array}$ & $\begin{array}{l}14.4 \pm 0.24(5) \\
13.9 \pm 0.59(8) \\
15 \cdot 0 \pm 0.62(5) \\
13.4 \pm 0.75(4) \\
14.0 \pm 0.54(4) \\
15 \cdot 2 \pm 0.31(7)\end{array}$ & $\begin{array}{l}13.4 \pm 0.24(7) \\
12.1 \pm 0.35(7) \\
13.4 \pm 0.35(8) \\
10.4 \pm 0.37(5) \\
12.7 \pm 0.16(7) \\
13.3 \pm 0.62(3)\end{array}$ \\
\hline
\end{tabular}

TABLE III

EFFECT OF TWO DOSES OF NEPTAZANE GIVEN AT AN INTERVAL OF 12 HRS ON THE INTRA-OCULAR PRESSURE OF NORMAL AND GLAUCOMATOUS* EYES

\begin{tabular}{|c|c|c|c|c|c|c|c|}
\hline \multirow{3}{*}{$\begin{array}{l}\text { Case } \\
\text { No. }\end{array}$} & \multirow{3}{*}{ Diagnosis } & \multirow{3}{*}{$\begin{array}{l}\text { Dose } \\
\text { (mg.) }\end{array}$} & \multicolumn{5}{|c|}{ Intra-Ocular Pressure $†$} \\
\hline & & & \multirow{2}{*}{ Initial } & \multicolumn{4}{|c|}{ After Neptazane } \\
\hline & & & & $1 \cdot 5 \mathrm{hrs}$ & $4 \mathrm{hrs}$ & $24 \mathrm{hrs}$ & $28 \mathrm{hrs}$ \\
\hline $\begin{array}{l}1 \\
2 \\
3 \\
4 \\
5 \\
6 \\
7 \\
8 \\
9\end{array}$ & $\begin{array}{l}\text { Normal } \\
\text { Normal } \\
\text { Normal } \\
\text { Normal } \\
\text { Normal } \\
\text { Normal } \\
\text { Glaucoma } \\
\text { Glaucoma } \\
\text { Glaucoma }\end{array}$ & $\begin{array}{l}250 \\
250 \\
250 \\
250 \\
125 \\
125 \\
250 \\
250 \\
125\end{array}$ & $\begin{array}{l}17 \\
20 \cdot 5 \\
16 \cdot 0 \\
18 \cdot 0 \\
18 \cdot 5 \\
18 \\
30 \\
26 \\
35\end{array}$ & $\begin{array}{l}13 \\
17 \cdot 1 \\
12 \\
14 \\
16 \\
15 \\
26 \\
23 \\
30\end{array}$ & $\begin{array}{l}13 \\
17 \\
13 \\
14 \\
16 \\
15 \\
22 \\
23 \\
22\end{array}$ & $\begin{array}{l}13 \\
17 \\
12 \\
14 \cdot 5 \\
15 \\
14 \\
23 \\
20 \\
-\end{array}$ & $\begin{array}{l}14 \cdot 5 \\
16 \cdot 5 \\
\overline{14 \cdot 5} \\
18 \cdot 5 \\
18 \\
= \\
-\end{array}$ \\
\hline
\end{tabular}

* The glaucoma patients were under miotic treatment before and during the course of these observations.

+ Intra-ocular pressure was recorded with a Schiötz X-tonometer.

In the glaucoma patients, a fall in intra-ocular pressure was observed within 1 to $2 \mathrm{hrs}$ after 250 or $125 \mathrm{mg}$. Neptazane. No side-effects were noted except in the patient given $125 \mathrm{mg}$. who experienced a tingling sensation in her feet and hands.

\section{Discussion}

The observed effects of carbonic anhydrase inhibitors on the intra-ocular pressure indicate that in animals and man Neptazane is two to three times more active than an equal weight of Diamox. As the molecular weights of these two inhibitors are very similar, this conclusion also holds when doses are expressed in equimolecular weights. In rabbits and cats the minimal dose of Neptazane that induced a fall in the intra-ocular pressure and in the rate of aqueous humour formation was 1 to $2 \mathrm{mg} . / \mathrm{kg}$., while in similar experiments 2 to $5 \mathrm{mg} . / \mathrm{kg}$. Diamox were required to give the same 
results. In human subjects the values were similar, the minimal doses of Neptazane and Diamox needed to produce a fall in the intra-ocular pressure being approximately 1 to 3 and 3 to $7 \mathrm{mg}$. $/ \mathrm{kg}$. respectively.

In attempting to assess the comparative activity of Neptazane and Diamox beyond their immediate action on the intra-ocular pressure, one is faced by apparent differences in the reaction of man and animals to these inhibitors, and also by the fact that the optimal conditions necessary to sustain the action of these inhibitors on the glaucomatous human eye have not yet been completely clarified (Campbell, Jones, Renner, and Tonks, 1957). In the experiments on rabbits, evidence of a partial recovery of the intra-ocular pressure was observed within 2-3 hrs of an injection of Neptazane, and it is uncertain to what degree this represented a recovery in the rate of aqueous humour formation or an increase in the outflow resistance (see Langham, 1958a).

The results of the studies on man confirmed the conclusion of Grant and Trotter (1954), that the intra-ocular pressure of normal subjects might be depressed for days by the periodic administration of Diamox, and also suggested that the effects of Neptazane were similar in this respect. The action of Neptazane was of particular interest in that the effects of a 250-mg. dose lasted for at least $20 \mathrm{hrs}$, while a dose of $125 \mathrm{mg}$. depressed the intraocular pressure for more than $12 \mathrm{hrs}$. By way of comparison after a single dose of $250 \mathrm{mg}$. Diamox the intra-ocular pressure of normal subjects recovered within 6 to $8 \mathrm{hrs}$ (Campbell, Tonks, and Jones, 1956).

The specificity of the reactions of Neptazane and Diamox on the eye is evident from the observations made with the control compounds which have very similar chemical structure but no carbonic anhydrase inhibitory activity and which do not reduce the intra-ocular pressure. From these findings and the conclusion that Neptazane is more active than Diamox in causing a fall in the intra-ocular pressure, it would appear probable that the ability of carbonic anhydrase inhibitors to lower the intra-ocular pressure could be assessed from their activity in vitro.

The transient changes in the blood pressure and intra-ocular pressure caused by the rapid intravenous injection of Neptazane, Diamox, or their control compounds, were almost certainly caused by the alkaline properties of their sodium salts. All these compounds act as fairly strong buffers in the $\mathrm{pH}$ range of $7 \cdot 0$ to $10 \cdot 0$, and, as solutions of their sodium salts have a $\mathrm{pH}$ of 9.0 to 10.0 , some rise in blood $\mathrm{pH}$ at the site of injection must have taken place. This explanation is consistent with the observation that the transient pressure changes were not seen when the compounds were injected slowly.

The direct measurements of the rate of formation of the aqueous humour demonstrated unequivocally that carbonic anhydrase inhibitors can cause a fall in the rate of flow, and they confirmed previous conclusions based on the indirect procedures of tonography (Becker and Constant, 1955), fluor- 
escein appearance times (Langham and Lee, 1957), and chemical analysis (Becker, 1956). The fall in the rate of aqueous humour formation took place immediately after the injection of the inhibitor, and the time course of these changes agreed closely with those which took place in the intraocular pressure. It is therefore probable that the fall in intra-ocular pressure in this initial stage is determined completely by the decreased rate of formation of the aqueous humour.

\section{Summary}

(1) This investigation deals with the influence on the eye of Neptazane, a new carbonic anhydrase inhibitor. In particular, an attempt has been made to compare its activity with that of the well-known carbonic anhydrase inhibitor, Diamox. In further experiments, the specificity of the reaction of these two compounds in decreasing the intra-ocular pressure and the rate of formation of the aqueous humour have been studied with the aid of compounds having similar chemical structure but possessing no inhibitory activity.

(2) From manometric records of the intra-ocular pressure and blood pressure of rabbits and cats, it was found that Neptazane in a dose as small as $1 \mathrm{mg} . / \mathrm{kg}$. lowered the intra-ocular pressure independently of the blood pressure. In this respect it appeared to be two to three times more active than Diamox. Similar effects were observed in conscious rabbits, a tonometric technique being used to estimate the intra-ocular pressure. Relatively high doses of the control compounds did not influence the intra-ocular pressure.

(3) The effect of these compounds on the rate of formation of the aqueous humour has been determined by a new technique which allows direct measurement of aqueous humour formation in conditions of constant pressure (Langham, 1958b). With this procedure it was found that Neptazane caused an immediate decrease in the rate of aqueous humour formation in rabbits and cats after an intravenous injection of $1 \mathrm{mg} . / \mathrm{kg}$., whereas a positive effect was not obtained with Diamox with doses less than $2 \mathrm{mg} . / \mathrm{kg}$. The time course of the change in aqueous humour formation was found to agree closely with that of the fall in intra-ocular pressure. The control compounds did not influence the rate of formation of the aqueous humour.

(4) In human subjects, Neptazane was found to decrease the intra-ocular pressure of normal and glaucomatous eyes, and to be effective at a lower dosage than Diamox. A single dose of $250 \mathrm{mg}$. Neptazane was found to depress the intra-ocular pressure for a period of at least $20 \mathrm{hrs}$.

I should like to express my deep appreciation to Prof. Cogan and Dr. M. Grant for giving me the facilities to do this study, and to Prof. T. Maren for his advice. I am also indebted to the Alfred P. Sloan Foundation for financial help towards the cost of the equipment used in this study. 


\section{REFERENCES}

BeCKER, B. (1955). “Acta XVII Conc. Ophthal., 1954, Canada, U.S.A.”, vol. 3, p. 1557. (1956). Amer. J. Ophthal., 41, 522. (1957). A. M. A. Arch. Ophthal., 58, 862.

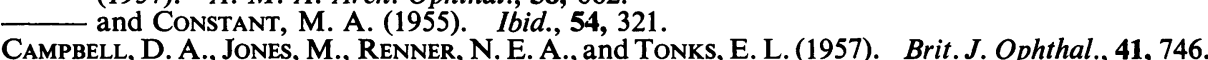
, TONKS, E. L., and JONES, M. (1956). Ibid., 40, 283.

Grant, W. M., and Trotter, R. R. (1954). A. M. A. Arch. Ophthal., 51, 735.

KREBS, H. A. (1948). Biochem. J., 43, 525.

Langham, M. E. (1958a). Physiol. Rev., 38, 215. $(1958 \mathrm{~b})$. In press. and LEE, P. M. (1957). Brit. J. Ophthal., 41, 65.

MANN, T., and KeILIN, D. (1940). Nature (Lond.), 146, 164.

MAREN, T. H. (1956). J. Pharmacol. exp. Ther., 117, 385. 